\title{
Excisão cirúrgica associada ao tratamento tópico com pomada à base de metronidazol, óleo de copaíba e papaína em pitiose equina
}

Camila da Silva Ferreira", Mariana Motta de Castro, Wericsson da Silva Borges, Amanda Piletti, Sergio Freire dos Santos Junior, Luana Domingos de Souza, Mariane Alves Ponciano, Delfino Álvares Pereira da Silva

Faculdade Anhanguera, Dourados, MS, Brasil

*Autor correspondente

e-mail: camilavetufms@hotmail.com

\section{Resumo}

A pitiose em equinos é uma doença ulcerativa, proliferativa na pele e tecido subcutâneo, causada pelo oomiceto Pythium insidiosum. É caracterizada pela formação de granulomas eosinofílicos, com a presença de massas necróticas chamadas de kunkers. Um equino, fêmea, mestiça Quarto de Milha, pelagem castanha, 6 anos de idade, pesando $360 \mathrm{~kg}$, foi encaminhada ao Hospital Veterinário da Faculdade Anhanguera de Dourados/MS no mês de abril de 2016, por apresentar uma lesão granulomatosa na região medial do membro posterior esquerdo. De acordo com o responsável pelo animal, a lesão havia sido percebida há cerca de seis meses, com o aparecimento de um nódulo de pele localizado na região medial da coxa esquerda. A lesão apresentou crescimento progressivo e tornou-se uma extensa ferida com presença de secreção sanguinolenta e recoberta por crostas. Ao exame físico, notou-se uma massa firme de aspecto granulomatoso, medindo aproximadamente $40 \mathrm{~cm}$, com presença de exsudato serossanguinolento e concreções de coloração amarelada; suspeitou-se de pitiose cutânea. 0 tratamento consistiu-se na excisão cirúrgica da massa granulomatosa, seguida de cauterização com ferro quente. Para a realização do procedimento, o animal foi anestesiado com cloridrato de xilazina $2 \%$ associado a cloridrato de quetamina $10 \%$, ambos por via endovenosa. Na manutenção do plano anestésico, utilizou-se éter gliceril guaiacol (EGG) em infusão contínua pela via endovenosa. Depois de realizada a antissepsia, utilizou-se cloridrato de lidocaína $2 \%$ como anestésico local. Após a ressecção, amostras da lesão foram coletadas e fixadas em formol $10 \%$ para realização de análise histopatológica, que revelou tecido subcutâneo com acentuada proliferação de tecido conjuntivo fibroso com formações grosseiramente esféricas, constituídas de um centro hipereosinofílico, resultante da degranulação de eosinófilos. Nessas áreas, frequentemente foram observadas imagens negativas de hifas pseudoseptadas. No pós-cirúrgico, administrou-se 1,1 mg/Kg de flunixina meglumina durante cinco dias, além de $2 \mathrm{mg} / \mathrm{Kg}$ de ceftiofur sódico por seis dias, ambos pela via 
intramuscular a cada $12 \mathrm{~h}$. A ferida era higienizada duas vezes ao dia com clorexidina $2 \%$ e iodopolividona $10 \%$. Após cada higienização, utilizava-se de forma tópica pomada à base de metronidazol 1\%, óleo de copaíba $15 \%$ e papaína $2 \% .0$ tratamento tópico foi realizado durante 90 dias, até a completa cicatrização da ferida. No animal em questão, não foi utilizado iodeto de potássio e a cura com remissão da lesão foi possível com a excisão cirúrgica e uso da pomada, acendendo, assim, uma nova possibilidade para o tratamento de animais acometidos por Pythium insidiosum.

Palavras-chave: Pythium. Kunkers. Neoplasia. 